\title{
The Knowledge of Primary Health Care System among Patients Accessing Health Care in Supreme Faith Hospital, Ado-Ekiti, Nigeria
}

\author{
Article by Pius Izundu Okpoko \\ Texila American University, Nigeria \\ E-mail: supfaith2000@yahoo.com
}

\begin{abstract}
Objective: To determine the knowledge of Primary health care system among patients who access health care in Supreme Faith Hospital, Ado-Ekiti, Nigeria.

Study design and Setting - A cross-sectional study design that made use of quantitative survey method involving data collection and analysis.

Participants - 120 voluntary adults who access health care services at Supreme Faith Hospital, Ado-Ekiti, Nigeria.

Method: A semi-structured questionnaire was administered to participants who also consented to the survey. A cross-sectional study was deemed fit for this research because it enables any desired data to be collected at one point in time.

Results: There were 38 (31.7\%) males as against 82 (68.3\%) females in the study. Majority of the respondents fell within high reproductive age group, 21-30. The respondents who indicated that they were aware/have knowledge of PHC in the study were 98 (81.7\%), while those who were ignorant of PHC were 22 (18.3\%).

Conclusions: The awareness of PHC was high among patients who access health care in Supreme faith hospital. 98 (81.7\%) out of 120 respondents studied were aware of PHC. Although there was high level of awareness of the services of PHC, a sizeable number of patients preferred secondary health care facilities to primary health care. PHC facilities should be strengthened through investment in facility, staffing, and training of the already engaged workforce.
\end{abstract}

Keywords: Awareness, Facilities, knowledge, Patients, Primary health care, Public health.

\section{Introduction and background}

The World Health Organisation defined Primary health care (PHC) as "essential health care based on practical, scientifically sound, and socially acceptable methods and technology made universally accessible to individuals and families in the community through their full participation and at a cost that the community and country can afford to maintain at every stage of their development in the spirit of self-reliance and self-determination" (WHO, 2011:p.1). This singular definition which expresses the true meaning and essence of Primary health care was to serve as a prompter and a stepping-stone in addressing the gross inequality that exists in the health status of the people of different countries as indicated by the declaration of Alma-Ata (WHO, 2011). However, the Primary health care is yet to achieve its goals especially in subSaharan Africa; Nigeria being a part of this region. Nigeria health indicators are still one of the poorest in the world (see Table 1). Life expectancy at birth in years $(2012)=52.1$, Maternal mortality ratio $(2008-2012$, reported cases $)=550$, Under-five mortality rate $($ U5MR, 2012) $=$ 124 , and Infant mortality rate $(2012)=78$ (UNICEF, 2013). Government public spending as a percentage of GDP allocated to health in the year 2007-2011 was only 2 per cent (UNICEF, 2013).

Table 1. Some health indicators of Nigeria (UNICEF, 2013)

\begin{tabular}{ll}
\hline Life expectancy at birth in years (2012) & 52.1 \\
Maternal mortality ratio (2008-2012, reported & 550 \\
cases) & \\
Under-five mortality rate (U5MR, 2012) & 124 \\
$\quad$ Infant mortality rate (2012) & 78 \\
\hline
\end{tabular}


The Primary health care system in Nigeria is adjudged as the bedrock of Nigerian health care policy. Although, considered as highly ineffective owing to inadequate investment in facilities, man power and the provision of essential drugs (NAS, n.d.), the Primary health care remains the first point of contact for patients seeking preventive, health promoting, curative and rehabilitative services in Nigeria (NAS, n.d.). Rabiu (2010) observes that increased accessibility of patients to PHC has the rare advantage of improving public health. However, the deplorable state of PHC facilities being witnessed in different geopolitical zones in Nigeria appears to have created absence of confidence and trust on the part of the general populace who access these facilities. Again, there appears to be shallow knowledge on the part of patients as per the true functionality and services of the Primary health care and other levels of health care systems like the secondary and Tertiary care.

Primary health care serves as the day-to-day care which is essentially needed to protect, maintain or restore the health of the populace. It is designed to be the patients' first point of contact with the health care system and their most frequently used health service. On the other hand, secondary and tertiary health care facilities are referral centres for more severe health problems and chronic illnesses. A visit to a family physician, an interaction with a pharmacist to discuss prescribed drugs, or discussing with a registered nurse on basic health issues are all examples of how Nigerians access primary health care on daily basis. Also, 'medical quackery' abounds in many locations in the country. Uninformed patients patronise them in an attempt to get cheaper and affordable health care. There are trado-medical units, also.

The objective of this study, therefore, is to determine the knowledge of Primary health care system among patients who access health care in Supreme Faith Hospital, Ado-Ekiti, Nigeria.

\section{General considerations}

\section{A review of literature on primary health care}

Many writers and researchers have looked into Primary health care (PHC) from different perspectives that include accessibility to care, organization of Primary health care, factors affecting Primary health care systems, funding, etc. But, there is gross lack of literature on the knowledge/awareness of primary health care among the populace who are to use the facilities.

Knowledge of PHC and what it stands to represent is very pertinent to its accessibility. It is known that the four cardinal components of PHC in Nigeria are: (1) universal coverage, (2) people centred care, (3) inclusive leadership and (4) health in all policies (Omoabike, 2010). These components of PHC are pivotal to its success in Nigeria. Omoabike (2010) observes that lack of enough publicity, poor and/or lack of community buy-in the running of the health care centres and lack of adequate number of personnel to man PHC centres are the major issues militating against the PHC system.

In an event when there is moderate level of publicity, illiteracy may stand a chance of deterring the effort being made except communication is tailored down to the socio-cultural level of participating communities. Iyayi (2009) agreed that socio-cultural factors can influence the PHC services in Nigeria. Cultural beliefs and taboos, unemployment, illiteracy, gender inequality, poverty and income inequality, availability and distribution of health human resources, etc., were observed to have a great impact on the PHC services in Nigeria (Iyayi, 2009). A critical appraisal of the above factors will suggest a direct/indirect impact on access to the primary health care facilities in Nigeria. Nevertheless, further details of the said impact were not analysed using a thoroughly carried out research.

Can illiteracy contribute to having inadequate knowledge of PHC and its services in Nigeria? UNICEF (2013) observers that the primary school net attendance ratio in 2008-2012 among the poorest 20 percent of the population in Nigeria was 33.6. Nigeria, though a known oil-rich nation, still has about $60 \%$ (or more) of her population under abject poverty.

Apart from having a clear knowledge of PHC which can contribute to its access, Sanmartin et al (2004) also identified two barriers to health care access as difficulty in contacting the health care provider during routine care and long waits before accessing urgent care. This finding was supported by Sanmartin and Ross (n.d) while researching on the difficulties patients experience in 
accessing first contact health care services, though this research was done in Canada. Leopantro (2010) submitted that the problem with PHC facilities in Nigeria should not be narrowed only to inadequate structure, lack of medical equipments and laboratory facilities, and inadequate staffing, but enhancing orientation of the populace in the utilization of health care services is very essential.

Ghana, a West African country with a population of about 26 million people, has its health care facilities largely provided by the government. Van den Boom et al (2004) noted that access to health care facilities remained a problem. Issues, like non-uniformity in distribution of medical facilities across the country with most rural areas lacking basic health facilities as well as doctors and nurses, still plague Ghana. However, in the early 1990s, the Government of Ghana embarked on a health sector reform to improve the accessibility and quality of services. Presently, the healthcare system in Ghana is organised under four main categories of delivery systems: public, private-for-profit, private-not-for-profit and traditional systems (ACCORD, 2009).

Another sub-Saharan African country worth considering is Liberia. The nation's fourteen years of conflict contributed in no small measure to deterioration of health care services. There is, however, a gradual expansion in humanitarian emergency health actions to accessible areas of the country. WHO (2006) observes that the health care delivery system is still in its emergency phase and is heavily dependent on additional external resources in order to improve on primary health care coverage and increase human and institutional capacity. Liberia health care system is still highly reliant on support from donor Agencies and Nongovernmental organisations. Access to basic and secondary health care services in the country is still a big challenge (WHO, 2006).

\section{About health care delivery in nigeria}

Health care delivery in Nigeria, as in other parts of Africa, takes the form of the basic health care services which are covered by the PHC, and the more severe/challenging health problems that are managed by referral centres i.e. the secondary and tertiary facilities. Patients' first point of contact with health care professionals is the PHC. Under this system, majority of cases are attended to. However, a systematic and orderly protocol exists which affords a patient the opportunity of consulting a Specialist (Consultant) who works under the secondary or tertiary health care institution. Referral is done from PHC to secondary health care facility, and then, to tertiary health care unit.

A primary health care physician or a General Practitioner (GP) sees a patient and decides on the necessary line of medical management. There is asymmetry in information between the physician and the patient as per clinical management of any case in question which is not uncommon in health care market. In a situation when the case is beyond the capability of the PHC system, then a referral (letter) is given for more expert management at the secondary health care facility. Moreover, where there is a critical need for further management of the case, especially chronic case and terminal illness, the secondary health care facility refers the patient to the tertiary health care institution which is the highest level of health care system in Nigeria.

Box 1: Referral system in health care.

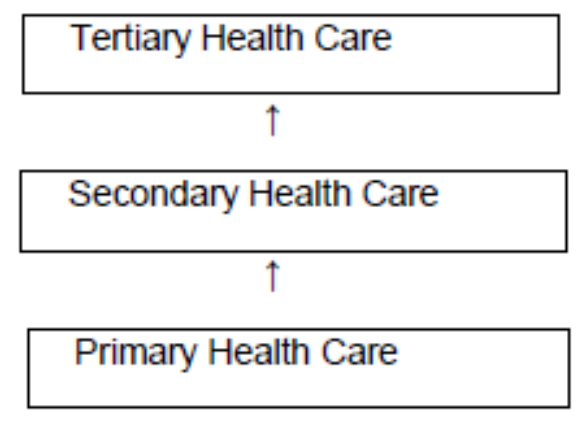

Presently, there is increasing advocacy about improving information flow among the three levels of health care services for better management of patients. Additionally, a feedback 
mechanism should be well established whereby the tertiary and secondary health care facilities inform the primary health care facility about the progress in health status of the referred patients.

\section{Primary health care system and policy in nigeria}

The federal government of Nigeria, under the leadership of President Ibrahim Babangida, launched its Primary Health Care (PHC) plan in August 1987. It was announced as the cornerstone of health policy of the country with the aim of positively affecting the entire national population. The main objectives of PHC included:

1) Accelerated health care personnel development,

2) Improved collection and monitoring of health data,

3) Ensuring availability of essential drugs in all areas of the country,

4) Implementation of an Expanded Programme on Immunization (EPI),

5) Improved nutrition throughout the country,

6) Promotion of health awareness,

7) Development of a national family health program, and

8) Widespread promotion of oral rehydration therapy for treatment of diarrheal disease in infants and children.

The effective implementation of the above mentioned programmes was intended to be carried out majorly through collaboration between Nigerian Ministry of Health and participating local government councils, which received direct grants from the federal government (LCCS, 2005). The stated objectives were, however, far from being realised. It was not until after about two decades later that the federal government started realising that it would not fulfil its vision without adequate involvement of the private sector of the economy. The primary health care is still dwindling in its progress and many facilities are moribund as regards their services (Rabiu, 2010). Leopantro (2010) opined that the challenges facing PHC facilities in Nigeria should not be narrowed only to inadequate structure, lack of medical equipments and laboratory facilities, and inadequate staffing, but enhancing orientation of the populace in the utilization of health-care services is very essential.

Although the program on EPI was said to have made much progress by the government, its goal of 90 percent coverage was probably excessively ambitious (LCCS, 2005). The available data from UNICEF (2013) revealed the following: immunisation coverage (\%) in 2012 for BCG was 60 percent, DPT1 was 47 percent, DPT3 was 41 percent, Polio3 was 59 percent, MCV was 42 percent, HepB3 was 41 percent, Hip3 was 10 percent, and new born protected against Tetanus was 60 percent.

The above figures are far from the targeted goal of the PHC after several years of its inception. Meanwhile, some international organisations, like Bill and Melinda Gates Foundation, are making much input into the control of communicable diseases in Nigeria and other developing nations.

\section{Methods}

\section{Study setting}

This quantitative study was done at the out-patient department of the chosen facility (Supreme Faith Hospital, Ado-Ekiti, Nigeria). The hospital operates as a primary and secondary health care facility.

\section{Ethical clearance}

Permission was obtained from the Supreme Faith Hospital Ethics' committee, and written consent (in form of a 'ticked consent') was also obtained from the participants after due explanation of the survey and assurance of anonymity and confidentiality.

\section{Study design}

This was a cross-sectional survey that made use of semi-structured, pre-tested questionnaire which was given to volunteers to complete. 


\section{Epistemological approach}

The research was a quantitative study that assumes positivism. Positivism shapes reality to be objective and combines a deductive approach with precise measurement of quantitative data to predict human behaviour (Neuman, 2000).

\section{Inclusion criteria}

Adults attending the out-patient clinic who gave their consent.

Fully 'conscious and alert' inpatients who were able to answer questions adequately.

\section{Exclusion criteria}

Severe emergencies, including unconscious patients, were excluded from the study.

Very young children were excluded, also.

Those with severe mental/psychiatric illness were also excluded.

\section{Sample size estimation}

This was estimated to be 120 . The sample size was calculated using the formula:

$$
\mathrm{n}=\mathrm{Z}^{2} \mathrm{pq} / \mathrm{d}^{2}
$$

Where $\mathrm{z}=$ standard normal deviation which is usually placed at 1.96 and corresponds to the 95\% confidence level.

$\mathrm{P}=$ the proportion in the target population estimated to have a particular characteristic or prevalence rate obtained from a previous research. Here $\mathrm{P}=50 \%$, since there has not been any previous study.

$$
\mathrm{q}=(1-\mathrm{p})
$$

$\mathrm{d}=$ degree of accuracy desired which is usually set at 0.05 (Araoye, 2003). This is for a population of $\geq 10,000$.

However, our sample population was $<10,000$. Therefore, $\mathrm{nf}$ i.e. desired/adequate sample size of population $<10,000$ is given as:

$\mathrm{nf}=1+\mathrm{n} / \mathrm{N}$.

\section{Data collection}

The researcher and trained assistants distributed the questionnaire and collected data within the month of May, 2014. The content of the questionnaire was carefully translated in local language to participants who were unable to read English without altering the meaning of each question. The questionnaires were immediately collected from the participants after answering them to avoid loss on transit.

\section{Results}

This section presents the result of the cross-sectional study design. A total of 120 questionnaires were distributed, completed and returned which gave $100 \%$ response rate for the study. All the returned questionnaires were analysable.

\section{Socio-demographic distribution of participants}

The socio-demographic distribution of the participants in the study is indicated in the Table below (Table 2). 
DOI: $10.21522 / \mathrm{TIJPH} .2013 .05 .04$.Art054

ISSN: $2520-3134$

Table 2. Socio-demographic distribution of participants

\begin{tabular}{|c|c|c|c|c|c|}
\hline $\begin{array}{l}\text { COVARIA } \\
\text { TE }\end{array}$ & $\begin{array}{l}\text { FREQU } \\
\text { ENCY }\end{array}$ & $\begin{array}{l}\text { PERCENTA } \\
\text { GE }\end{array}$ & $\begin{array}{l}\text { COVARIA } \\
\text { TE }\end{array}$ & $\begin{array}{l}\text { FREQU } \\
\text { ENCY }\end{array}$ & $\begin{array}{l}\text { PERCENTA } \\
\text { GE }\end{array}$ \\
\hline AGE & & & GENDER & & \\
\hline \multicolumn{6}{|l|}{ GROUP } \\
\hline$<=20$ & 11 & 9.2 & Male & 38 & 31.7 \\
\hline $21-30$ & 58 & 48.3 & Female & 82 & 68.3 \\
\hline $31-40$ & 39 & 32.5 & Total & 120 & 100.0 \\
\hline $41-50$ & 9 & 7.5 & $\begin{array}{l}\text { EMPLOY } \\
\text { MENT } \\
\text { STATUS }\end{array}$ & & \\
\hline $\begin{array}{l}51 \text { and } \\
\text { above }\end{array}$ & 3 & 2.5 & Employed & 46 & 38.3 \\
\hline \multirow[t]{4}{*}{ Total } & 120 & 100.0 & $\begin{array}{l}\text { Not } \\
\text { employed }\end{array}$ & 40 & 33.3 \\
\hline & & & Student & 29 & 24.2 \\
\hline & & & Apprentice & 5 & 4.2 \\
\hline & & & Total & 120 & 100.0 \\
\hline \multicolumn{6}{|l|}{$\begin{array}{l}\text { MARITAL } \\
\text { STATUS }\end{array}$} \\
\hline Single & 46 & 38.3 & & & \\
\hline Married & 67 & 55.8 & & & \\
\hline Separated & 4 & 3.3 & & & \\
\hline Divorced & 2 & 1.7 & & & \\
\hline Widowed & 1 & 0.8 & & & \\
\hline Total & 120 & 100 & & & \\
\hline \multicolumn{6}{|l|}{ EDUCATI } \\
\hline \multicolumn{6}{|l|}{ ONAL } \\
\hline \multicolumn{6}{|l|}{ STATUS } \\
\hline Primary & 12 & 10.0 & & & \\
\hline Secondary & 80 & 66.7 & & & \\
\hline Tertiary & 22 & 18.3 & & & \\
\hline None/Other & 6 & 5.0 & & & \\
\hline $\mathrm{s}$ & & & & & \\
\hline Total & 120 & 1.00 & & & \\
\hline
\end{tabular}

The majority of respondents were within the age group of 21-30, followed by age group of 3140. Also, the majority of the respondents were females. Meanwhile, the majority of respondents were married which corresponds with the age group of highest number of respondents i.e. high reproductive age group.

Table 3. Present educational status Vs 'Are you aware of the primary health care system in Nigeria?'

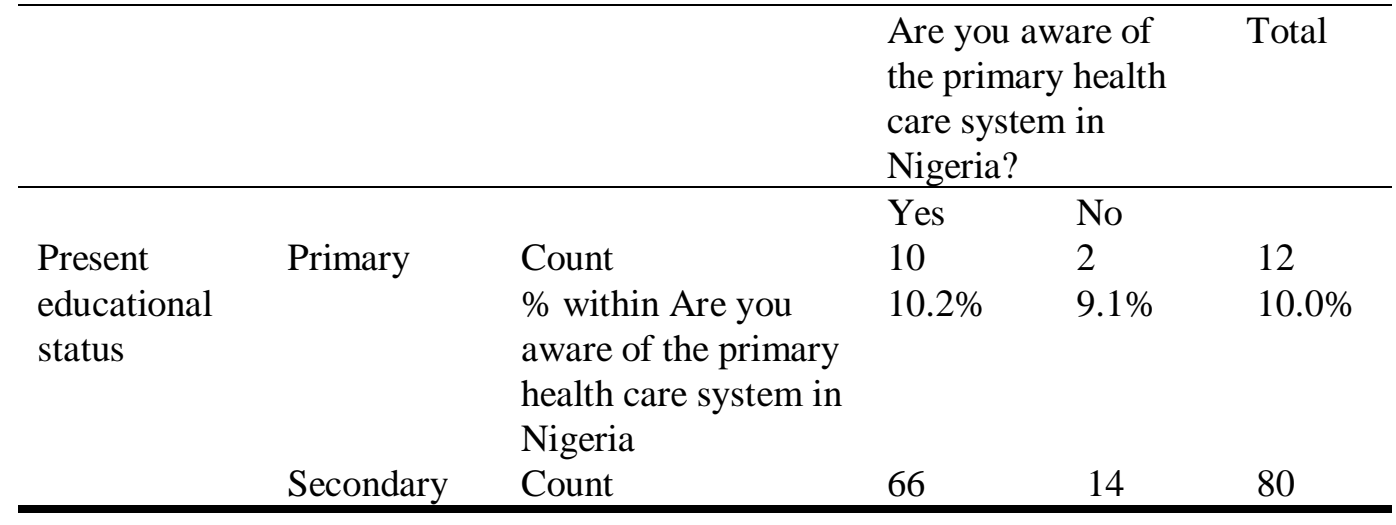


Volume 5, Issue 4, Dec 2017

\begin{tabular}{|c|c|c|c|c|c|}
\hline & & $\begin{array}{l}\% \text { within Are you } \\
\text { aware of the primary } \\
\text { health care system in } \\
\text { Nigeria }\end{array}$ & $67.3 \%$ & $63.6 \%$ & $66.7 \%$ \\
\hline & Tertiary & Count & 17 & 5 & 22 \\
\hline & & $\begin{array}{l}\% \text { within Are you } \\
\text { aware of the primary } \\
\text { health care system in } \\
\text { Nigeria }\end{array}$ & $17.3 \%$ & $22.7 \%$ & $18.3 \%$ \\
\hline & None/Others & Count & 5 & 1 & 6 \\
\hline & & $\begin{array}{l}\% \text { within Are you } \\
\text { aware of the primary } \\
\text { health care system in } \\
\text { Nigeria }\end{array}$ & $5.1 \%$ & $4.5 \%$ & $5.0 \%$ \\
\hline Total & & Count & 98 & 22 & 120 \\
\hline & & $\begin{array}{l}\% \text { within Are you } \\
\text { aware of the primary } \\
\text { health care system in } \\
\text { Nigeria }\end{array}$ & $100.0 \%$ & $100.0 \%$ & $.0 \%$ \\
\hline
\end{tabular}

Table 3 presents the result of the association between educational status and awareness of primary health care system in Nigeria. The Pearson Chi-Square test gave a p-value $>0.05$ $(\mathrm{p}=0.95)$.

Table 4. Employment status Vs 'Are you aware of the primary health care system in Nigeria?'

\begin{tabular}{|c|c|c|c|c|c|}
\hline & & & \multicolumn{2}{|c|}{$\begin{array}{l}\text { Are you aware of the } \\
\text { primary health care } \\
\text { system in Nigeria? }\end{array}$} & \multirow[t]{2}{*}{ Total } \\
\hline & & & Yes & No & \\
\hline \multirow{8}{*}{$\begin{array}{l}\text { Employment } \\
\text { status }\end{array}$} & Employed & Count & 43 & 3 & 46 \\
\hline & & $\begin{array}{l}\% \text { within Are you } \\
\text { aware of the primary } \\
\text { health care system in } \\
\text { Nigeria }\end{array}$ & $43.9 \%$ & $13.6 \%$ & $38.3 \%$ \\
\hline & Not & Count & 28 & 12 & 40 \\
\hline & employed & $\begin{array}{l}\% \text { within Are you } \\
\text { aware of the primary } \\
\text { health care system in } \\
\text { Nigeria }\end{array}$ & $28.6 \%$ & $54.5 \%$ & $33.3 \%$ \\
\hline & Student & Count & 23 & 6 & 29 \\
\hline & & $\begin{array}{l}\% \text { within Are you } \\
\text { aware of the primary } \\
\text { health care system in } \\
\text { Nigeria }\end{array}$ & $23.5 \%$ & $27.3 \%$ & $24.2 \%$ \\
\hline & Apprentice & Count & 4 & 1 & 5 \\
\hline & & $\begin{array}{l}\% \text { within Are you } \\
\text { aware of the primary } \\
\text { health care system in } \\
\text { Nigeria }\end{array}$ & $4.1 \%$ & $4.5 \%$ & $4.2 \%$ \\
\hline \multirow[t]{2}{*}{ Total } & & Count & 98 & 22 & 120 \\
\hline & & $\begin{array}{l}\% \text { within Are you } \\
\text { aware of the primary } \\
\text { health care system in }\end{array}$ & $100.0 \%$ & $100.0 \%$ & $100.0 \%$ \\
\hline
\end{tabular}




\section{Nigeria}

Table 4 presents the result of the association between employment status and awareness of primary health care system in Nigeria. The Pearson Chi-Square test gave a statistical significant $\mathrm{p}$-value $<0.05$ ( $\mathrm{p}=0.045)$.

Table 5. 'Where do you think that a patient with a basic illness should go for treatment?' Vs 'Are you aware of the primary health care system in Nigeria'

\begin{tabular}{|c|c|c|c|c|c|}
\hline & & & & $\begin{array}{l}\text { Are you } \\
\text { aware of the } \\
\text { primary } \\
\text { health care } \\
\text { system in } \\
\text { Nigeria }\end{array}$ & Total \\
\hline \multirow{9}{*}{$\begin{array}{l}\text { Where do you } \\
\text { think that a } \\
\text { patient with a } \\
\text { basic illness } \\
\text { should go for } \\
\text { treatment }\end{array}$} & & & Yes & No & \\
\hline & Basic Health & Count & 51 & 11 & 62 \\
\hline & $\begin{array}{l}\text { Centre/Private } \\
\text { clinic }\end{array}$ & $\begin{array}{l}\% \text { within Are } \\
\text { you aware of } \\
\text { the primary } \\
\text { health care } \\
\text { system in } \\
\text { Nigeria }\end{array}$ & $52.0 \%$ & $50.0 \%$ & $51.7 \%$ \\
\hline & Specialist & Count & 38 & 8 & 46 \\
\hline & Hospital & $\begin{array}{l}\% \text { within Are } \\
\text { you aware of } \\
\text { the primary } \\
\text { health care } \\
\text { system in } \\
\text { Nigeria }\end{array}$ & $38.8 \%$ & $36.4 \%$ & $38.3 \%$ \\
\hline & Federal Medical & Count & 9 & 2 & 11 \\
\hline & $\begin{array}{l}\text { Centre/Teaching } \\
\text { Hospital }\end{array}$ & $\begin{array}{l}\% \text { within Are } \\
\text { you aware of } \\
\text { the primary } \\
\text { health care } \\
\text { system in } \\
\text { Nigeria }\end{array}$ & $9.2 \%$ & $9.1 \%$ & $9.2 \%$ \\
\hline & Others & Count & 0 & 1 & 1 \\
\hline & & $\begin{array}{l}\% \text { within Are } \\
\text { you aware of } \\
\text { the primary } \\
\text { health care } \\
\text { system in } \\
\text { Nigeria }\end{array}$ & $.0 \%$ & $4.5 \%$ & $.8 \%$ \\
\hline \multirow[t]{2}{*}{ Total } & & Count & 98 & 22 & 120 \\
\hline & & $\begin{array}{l}\% \text { within Are } \\
\text { you aware of } \\
\text { the primary } \\
\text { health care } \\
\text { system in } \\
\text { Nigeria }\end{array}$ & $100.0 \%$ & $100.0 \%$ & $100.0 \%$ \\
\hline
\end{tabular}

Table 5 presents the result of the association between the knowledge of hospitals' visit and awareness of primary health care system in Nigeria. The Pearson Chi-Square test gave a p-value $>0.05(\mathrm{p}=0.213)$. 
Table 6. 'What are some of the functions of primary health care system you know?' Vs 'Are you aware of the primary health care system in Nigeria?'

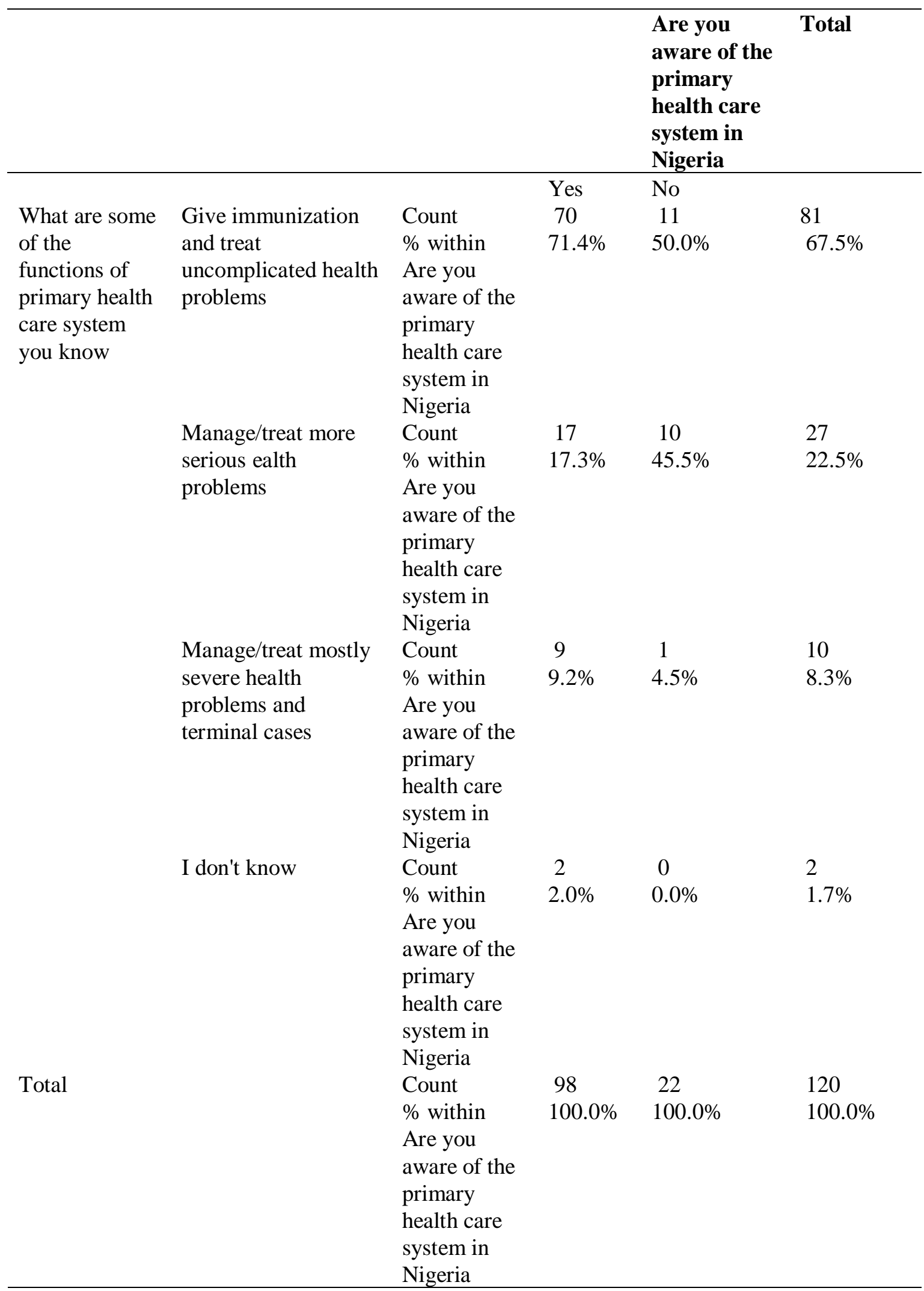

Table 6 presents the result of the association between the awareness of the functions of Primary health care and awareness of primary health care system in Nigeria. The Pearson ChiSquare test gave a statistical significant $\mathrm{p}$-value $<0.05(\mathrm{p}=0.038)$. 
DOI: $10.21522 /$ TIJPH.2013.05.04.Art054

ISSN: $2520-3134$

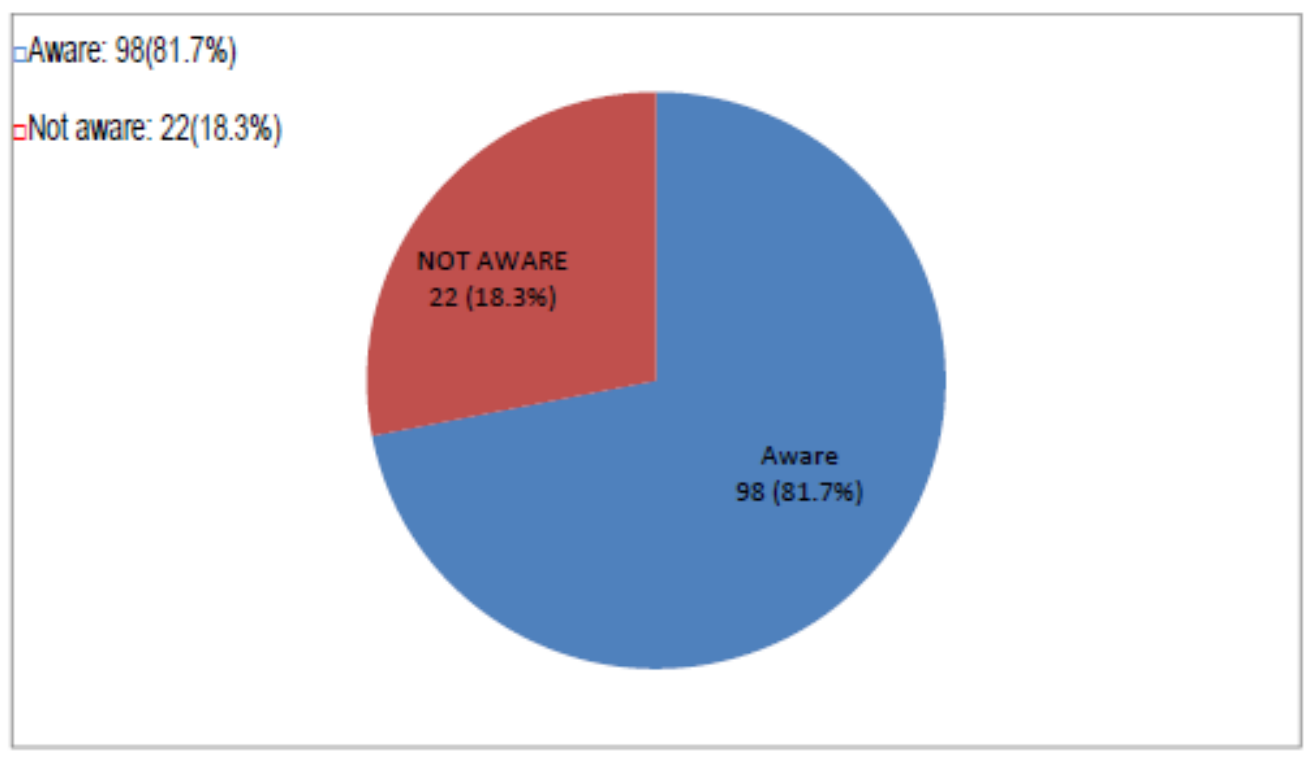

Figure 1. Pie chart showing knowledge/awareness of PHC among respondents

\section{Discussion}

The questionnaires distributed were 120. All the respondents completed and handed them over to the researcher. The data gathered in this study reveal that there were $38(31.7 \%)$ males as against $82(68.3 \%)$ females (Table 2). This agrees with the study done by Okpoko (2014) which indicated that more females access health care than males. Moreover, majority of the respondents fell within high reproductive age group, 21-30, (Table 2). According to Okpoko (2014), the high reproductive age group tends to access health care more than other age group within a specified period. This could be attributed to high health care need during antenatal, postnatal and subsequent child care period which are not uncommon with young women.

The respondents who indicated that they were aware/have knowledge of PHC in the study were $98(81.7 \%)$, while those who were ignorant of PHC were $22(18.3 \%)$. This shows that a sizeable number of respondents have knowledge of PHC among the studied group. Again, more respondents have knowledge of the basic functions of PHC 81 (67.5\%), and also knew that they should access health care at PHC when they have basic health challenges $62(51.7 \%)$ - see Tables 6 and 5, respectively. The decrease in the number of the later can be explained by additional respondents who, though they were aware of the functions of PHC, preferred specialist hospitals to PHC for basic health challenges (Table 6). In the submission on the research on the primary health care, Backer (1983) observes the need for improved research in the primary health services particularly in general practice. It was noted that it will consequently improve the knowledge of both the health practitioners and their patients, and greatly reduce the bias caused by situations like short physician-patient relationship.

Employment status was also studied. Those respondents who were employed were the majority among the respondents, $46(38 \%)$ - see Table $4.43 .9 \%$ of them have knowledge of PHC. This was closely followed by unemployed, $40(33.3 \%)$. Employment status was significant in the study, $\mathrm{p}=0.045$.

\section{Conclusion}

The awareness of PHC was high among patients who access health care in Supreme faith hospital. 98 (81.7\%) out of 120 respondents studied were aware of PHC. Although there was high level of awareness of the services of PHC, a sizeable number of patients preferred secondary health care facilities to primary health care. 


\section{Recommendations}

1) Since the present research is a quantitative research, more detailed and robust study is needed, e.g. qualitative study, to uncover further information on the researched topic.

2) Extensive dissemination of information about the services of PHC should be embarked upon in order for patients to be guided on where to access health care when needed.

3) Government should strengthen the PHC through investment in facility, staffing, and training of the already engaged workforce. This will encourage patients to access care at the PHC.

\section{References}

[1]. ACCORD (2009) 'Healthcare in Ghana', [Online]. Available at: http://www.ecoi.net/file_upload/90_1236873017_accord-health-care-in-ghana-20090312.pdf (Accessed: 23 May 2014).

[2]. AQR (2011) 'Pilot Study - definition', [Online]. Available from: http://www.aqr.org.uk/glossary/?term=pilotstudy (Accessed: 20 May 2014).

[3]. Araoye, M. (2003) Research Methodology with statistics for Health and Social Sciences. Ilorin: Nathadex publishers.

[4]. Backer, P. (1983) "Research in and on primary health care", US National Library of medicine; National Institutes of health, [Online]. Available at: www.nabinlm.nih.gov (Accessed: 09 September 2017). [5]. Bruce, N., Pope, D., \& Stanistreet, D., (2008) Quantitative Methods for Health Research: A Practical Interactive Guide to Epidemiology and Statistics. England: John Wiley \& Sons Ltd.

[6]. Green, J. \& Thorogood, N. (2009) Qualitative Methods for Health Research, $2^{\text {nd }}$ ed, London: SAGE publications Ltd.

[7]. Iyayi, F. (2009) "Socio - cultural factors influencing primary health care (PHC) services in Nigeria." Paper presented at Nigerian National Health Conference, Uyo, Akwa Ibom State, June9-10, 2009, [Online]. Available at: http://www.ngnhc.org/on (Accessed: 21 May 2014).

[8]. Leopantis, O. (2010) 'What are the major problems with the Primary Health Care in Nigeria', [Online]. Available at: http://www.nairaland.com/471320/what-major-problems-primary-health (Accessed: 21 May 2014).

[9]. Library of Congress (2005) "Nigeria Primary Health care". [Online]. Available at: http://www.photius.com/countries/nigeria/society/nigeria_society_primary_health_care_ 10006.html

(Accessed: 21 May 2014).

[10]. McGraw-Hill Concise Dictionary of Modern Medicine (2002) Health care access, [Online]. Available at: http://medicaldictionary.thefreedictionary.com/health+care+access (Accessed: 20 May 2014).

[11]. Neuman, L. (2000) Social Research Methods: Qualitative and Quantitative Approaches, Sydney: Allyn and Bacon.

[12]. Nigerian Academy of Science (n.d.) 'Primary Health Care System', [Online]. Available from: http://www.nas.org.ng/index.php?option=com_rokdownloads\&view=file\&task=do

wnload\&id=13\%3Aeffective-primary-health $1 \& I t e m i d=14$. (Accessed: 13 May 2014).

[13]. Okpoko, I. (2014) Public awareness of the National Health Insurance Scheme (NHIS) among patients accessing health care in Supreme Faith Hospital, Ado-Ekiti, Nigeria', [Online]. Available at: EInternational Journals of Academics \& Scientific Research (EIJASR), vol.4, issue 2,doi:10.21522/TIJPH.2013.04.02.Art016 (Accessed: 15 April 2016).

[14]. Omoabike, O. (2010) 'What are the major problems with the Primary Health Care in Nigeria', [Online]. Available at: http://www.nairaland.com/471320/what-major-problems-primary-health (Accessed: 21 May 2014).

[15]. Rabiu, R. (2010) 'Why primary healthcare must be enhanced', Daily Trust [Online]. Available from: http://www.news.dailytrust.com/index.php?option=com_content\&view=article\&id=13180: why-primaryhealthcare-must-be-enhanced\&catid=22:healthreport\&Itemid=124 (Accessed:13 May 2014).

[16]. Sanmartin, C., Gendron, F., Berthelot, J. and Murphy, K. (2004) Access to Health Care Services in Canada, 2003. Ottawa: Statistics Canada Cat. no. 82-575-XIE.

[17]. Sanmartin, C. and Ross, N. (2005) 'Experiencing Difficulties Accessing First-Contact Health Services in Canada', [Online]. Available from: http://www.longwoods.com/content/17882 (Accessed: 21 May 2014). 
DOI: $10.21522 /$ TIJPH.2013.05.04.Art054

ISSN: $2520-3134$

[18]. UNICEF (2013) 'At a glance: Nigeria', Statistics, [Online]. Available at: http://www.unicef.org/infobycountry/Nigeria_statistics.html (Accessed: 16 May 2014).

[19]. Van den Boom, G.J.M; Nsowah-Nuamah, N.N.N. and Overbosch, G.B. (2004) Healthcare Provision and

[20]. Self-medication in Ghana', [Online]. Available at: http://web.archive.org/web/20070625163825/http://www.saga.cornell.edu/images/vandenboom.pdf (Accessed: 22 May 2014).

[21]. World Health Organisation (2006) 'Liberia Health Sector needs assessment', [Online]. Available at: http://www.who.int/hac/donorinfo/cap/Liberia_compendium_Jan06.pdf (Accessed: 23 May 2014).

[22]. World Health Organisation (2011) 'Declaration of Alma-Ata; International Conference on Primary Health Care, Alma- Ata, USSR, 6-12 September 1978', p.1, [Online]. Available from: http://www.who.int/topics/primary_health_care/en/ (Accessed: 13 May 2014).

[23]. World Health Organisation (2011) 'Gender, Women and Health; Why gender and health?' [Online]. Available from: http://www.who.int/gender/genderandhealth/en/index.html (Accessed: 13 May 2014). 